'Programa de Biostadística, Escuela de Salud Pública, Facultad de Medicina, Universidad de Chile. Santiago, Chile. Unidad de Acústica Ambiental, Secretaría Regional Ministerial de Salud de la Región Metropolitana, Ministerio de Salud. Santiago, Chile. ${ }^{3}$ Programa de Salud Ambiental, Escuela de Salud Pública, Facultad de Medicina, Universidad de Chile. Santiago, Chile. ${ }^{4} F a c u l t a d$ de Ciencias de la Salud, Universidad de Tarapacá. Arica, Chile. aMSc. ${ }^{\mathrm{b}} \mathrm{PhD}$.

Noise measurement equipment, transport for field work, and professional and technical personnel of this study was provided by the Environmental Acoustics Unit of the Ministerial Secretary of Health of the Metropolitan Region. The authors did not receive any other type of financing for this research.

The authors declare no conflict of interest.

Recibido el 10 de enero de 2020, aceptado el 6 de mayo de 2020 .

Correspondencia a: Mauricio Fuentes Alburquenque Escuela de Salud Pública, Facultad de Medicina, Universidad de Chile. Av. Independencia № 939, Independencia. Santiago, Chile. mauricio.fuentes@uchile.cl

\section{Identification of daily environmental noise patterns in two different urban sites in Santiago, Chile}

\author{
MAURICIO FUENTES ALBURQUENQUE ${ }^{1, a}$, \\ ANTONIO MARZZANO RÍOS ${ }^{2, b}$, MAURICIO CANALS LAMBARRI ${ }^{3, b}$, \\ RODRIGO TORRES ARELLANO ${ }^{1, a}$, DANTE CÁCERES LILLO ${ }^{3, b}$, \\ SERGIO ALVARADO ORELLANA ${ }^{1,4, b}$
}

\begin{abstract}
Background: Environmental noise can cause auditory and non-auditory adverse effects. Aim: To identify daily environmental noise patterns in two urban sites of Metropolitan Santiago. Material and Methods: Continuous measurements of environmental noise in two sites of Metropolitan Santiago were analyzed by means of hierarchical cluster analysis. One site was a main street with heavy traffic and the second was a street from a neighborhood with intense nocturnal activity. The first phase of analysis consisted of clustering noise profiles with similar shapes according to the average linkage method, with correlation as the similarity measure. The second phase grouped the profiles with similar shapes into sub-clusters that also had similar absolute noise levels, using the complete linkage method, with absolute distance as the similarity measure. Results: Two noise patterns were identified for the first site, one for weekdays (Monday to Friday) and another for weekends (Saturday and Sunday). For the second site five different patterns were identified (Monday to Wednesday, Thursday, Friday, Saturday, and Sunday). Also different patterns appeared for summer compared to the rest of the year. The noise levels of both sites were high. Conclusions: The detected noise levels can be annoying, cause sleep disturbances and increase the risk for hypertension and cardiovascular diseases, among other effects.
\end{abstract}

(Rev Med Chile...)

Key words: Environmental Monitoring; Noise; Public Health, Cluster Analysis.

\section{Análisis de ruido ambiental en Santiago, Chile}

Antecedentes: El ruido ambiental puede tener efectos adversos auditivos y no auditivos. Objetivo: Identificar patrones diarios de ruido ambiental en dos sectores urbanos de Santiago, Chile. Material y Métodos: Se analizaron mediciones continuas de ruido ambiental realizadas en dos emplazamientos urbanos de Santiago, Chile, mediante análisis de cluster jerárquico. Los dos lugares fueron una avenida principal con alto tráfico vehicular y una calle en un barrio con intensa actividad nocturna. La primera fase del análisis agrupó perfiles de ruido con formas similares de acuerdo al método de vinculación promedio, usando la correlación como medida de similitud. La segunda fase agrupó los perfiles con formas similares en subclusters que también tuvieran niveles de ruido simila- 
res, usando el método de vinculación completa, con la distancia absoluta como medida de similitud. Resultados: Se identificaron dos patrones para el primer emplazamiento, uno para días de semana (lunes a viernes) y otro para fines de semana (sábado y domingo). Para el segundo emplazamiento se identificaron cinco patrones diferentes (lunes a miércoles, jueves, viernes, sábado, y domingo), así como patrones distintos para el verano en comparación con el resto del año. Los niveles de ruido en ambos lugares fueron altos. Conclusiones: Los niveles de ruido detectados podrían producir molestias, perturbación del sueño, incremento de riesgo de hipertensión y enfermedades cardiovasculares, entre otros efectos.

Palabras clave: Monitoreo del Ambiente; Ruido; Salud Pública.

\section{Introduction}

Environmental noise can cause both auditory and non-auditory health effects. Noise-induced hearing loss remains highly prevalent in occupational settings, and is increasingly caused by social noise exposure. Also, evidence of the non-auditory effects of environmental noise exposure on human health is growing. Several studies have proposed that noise exposure leads to annoyance, disturbs sleep and causes daytime sleepiness, increases hypertension and cardiovascular disease incidence, and impairs cognitive performance in schoolchildren $^{1-3}$. Loss of healthy life due to noise exposure have been estimated in billion of Euros in UK, and health of vulnerable people exposed to noise in Chile and the entire world is under-researched ${ }^{3}$.

Environmental noise is often assessed using acoustic descriptors that cover 24-hour periods, with weighted formulas to account for segments within a period, such as day-night $\left(\mathrm{L}_{\mathrm{dn}}\right)$ or day-evening-night $\left(\mathrm{L}_{\mathrm{den}}\right)$ levels, where $\mathrm{L}$ is the equivalent A-weighted sound pressure level, in dBA. Shorter assessment periods can also be used, such as for day $\left(\mathrm{L}_{\text {day }}\right)$, evening $\left(\mathrm{L}_{\text {evening }}\right)$ or night $\left(\mathrm{L}_{\text {night }}\right)$ levels. Descriptors are chosen based on the applicable guidelines, standards, and directives ${ }^{4-7}$ as well as the environmental noise typical of the local area ${ }^{8-17}$. In some situations, the hourly equivalent sound pressure level $\left(\mathrm{L}_{\text {Aeq, } 1 \mathrm{~h}}\right)$ for the noisiest hour of the day is informative ${ }^{18}$. For example, the acoustic impact of a project can be evaluated by measuring baseline noise level, identifying the periods of minimum and maximum noise levels, and then estimating the change in noise level attributable to the new development.

The above assessments may need to use the daily noise profile to determine typical sound patterns, which can be used to identify discrete periods of 1 hour or less to estimate noise levels for the remaining daily segments of interest.

The temporal behavior of environmental noise levels is clearly relevant to healthcare ${ }^{8,10,19-25}$. One approach to assessing temporal noise patterns is to adopt statistical methods that were originally developed for other areas of research, such as vehicular traffic, energy consumption and load, and human activity in cities ${ }^{26-33}$.

In this article, we studied daily noise patterns in two urban sites from Santiago, Chile, by means of hierarchical cluster analysis. The first is a main avenue with heavy traffic, and the second is a street in a neighborhood with intense nightlife activity. Acoustic descriptors are computed for each site, and risk for public health is assessed according to international recommendations.

\section{Materials and Methods}

\section{Noise measurements and software}

Data consisted of noise measurements taken by the Environmental Acoustics Unit from the Metropolitan Region Secretary of Health, the regional public health authority overseen by the Chilean Ministry of Health. Continuous noise recordings were taken at two sites in the capital city, Santiago, during 2008 and 2010, using Norsonic Nor121 sound level meter and Nor1225 outdoor microphone.

The first site was monitored for 13 consecutive days in 2008. This is located on Independencia Avenue (IA), a road with two lanes in both directions (for a total of four lanes) and significant bus and car traffic. Independencia Avenue is part of the Metropolitan Region trunk road network ${ }^{34,35}$. The measurement site was located at the Faculty of Medicine of the University of Chile. The noise recorded was mainly attributable to vehicular traffic. 
The second monitored site was on Pío Nono Street (PNS), which is also part of the Metropolitan Region trunk road network ${ }^{35-37}$. Unlike IA, PNS has no bus traffic and is a one-way street with two lanes. This is located in Bellavista neighbourhood (Santiago), which is a leisure zone with numerous bars and heavy pedestrian traffic. Measurements were taken during three campaigns in 2010, with a total of 35 days. The measurement equipment was installed on the fourth-floor balcony of a residential dwelling.

\section{Statistical analysis}

Statistical analyses were performed using R3.1.2 software ${ }^{38-41}$. It consisted in two phases of hierarchical cluster analysis, and results in final clusters with similar shapes and noise levels.

\section{Phase 1: Clustering by shape (similarity)}

The first step is to identify groups of days whose profiles have similar shapes. Given that days are the observations to be clustered, for a measurement of $n$ days, $\mathbf{x}_{i}=\left[\mathbf{x}_{i(1)}, \mathbf{x}_{i(2)}, \ldots, \mathbf{x}_{i(24)}\right]$ is the vector of observed values of $L_{\text {Aeq, }, ~}$ during $i$-th day $(i=1, \ldots, n)$, and $\mathbf{x}_{(k)}^{t}=\left[\mathbf{x}_{1(k)}, \mathbf{x}_{2(k)}, \ldots, \mathbf{x}_{n(k)}\right]$ is the transposed vector of the $k$-th observed hour $(k=1$, ..., 24). In other words, we have the data arranged in an $n \times 24$ matrix, whose rows (observations) are the $n$ days and columns (variables) are the 24 hours of the day.

The correlation coefficient $r_{i i}$ between two observations, $\mathbf{x}_{i}$ and $\mathbf{x}_{i}$, is a measure of the similarity of those vector profiles. The closer $r_{i i}$ is to 1 , the more similar the profiles ${ }^{42}$. In other words, two days, $i$ and $i$, have profiles with a similar shape when the correlation is positive and close to 1 .

Thus, the similarity measure used in Phase 1 was the Pearson correlation coefficient, with the average linkage method used for agglomerative hierarchical clustering. The most highly correlated clusters are then joined according to Equation $\mathrm{S} 1$. The cut-off value was defined as a correlation coefficient of 0.8 .

\section{Phase 2: Clustering by noise level (distance)}

Phase 1 might define clusters with substantially different absolute noise levels within them. Each of obtained clusters in the first phase contains days with profiles that are similar and, hence, parallel (Fig. S1). The focus in Phase 2 is on the proximity (or separation) among profiles, with the aim of identifying profiles with similar overall noise levels to identify subclusters.

An average hourly difference between noise levels of $2 \mathrm{dBA}$ was defined as the cut-off value for clustering. According to Equation S2 ${ }^{42-44}$, the absolute distance is the sum of differences for all of the variables, i.e., for all 24 hours of the day, so an average distance of $2 \mathrm{dBA}$ is represented by $\bar{d}_{i j}=d_{j j} / 24$. Thus, the cut-off value for absolute distance was $d_{i j}=24 \bar{d}_{j j^{\prime}}=48 \mathrm{dBA}$.

Phase 2 relies on the complete linkage method. Therefore, for two clusters $\mathrm{A}$ and $\mathrm{B}$, this proximity measure is defined as ${ }^{42-45} d_{\mathrm{AB}}=\max \left\{d_{\mathrm{ABjj}}\right\}$, where days $j$ and $j$ belong to clusters $\mathrm{A}$ and $\mathrm{B}$, respectively.

\section{Results}

\section{Case 1: Main street with heavy vehicular traffic (Independencia Avenue)}

Fig. 1 shows the hourly sound pressure levels for the 13 days monitored in 2008 at IA.

\section{Clustering by shape (similarity)}

Fig. S2a shows the dendrogram produced by the Phase 1 of the analysis. The correlation coefficient was higher than 0.8 (value below 0.2 on the vertical axis) for all pairs. Then, daily profiles for these 13 days were all fairly similar in shape.

\section{Clustering by noise level (distance)}

Fig. S2b shows the dendrogram produced by the Phase 2. A reference line corresponding to an absolute distance of 48 is shown. Two clusters were identified: weekdays (Mondays-Fridays) and weekend (Saturdays and Sundays). The mean daily profiles of the two clusters obtained have similar shapes but different absolute noise levels (Fig. 2). Variability was lower within the weekend cluster. This difference in noise levels associated to vehicular traffic between weekdays and weekends has been found in other studies s,45-47 $^{25}$

\section{Case 2: Street with pedestrian traffic and leisure activity (Pío Nono Street)}

Fig. 3 shows the hourly sound pressure levels for the 35 days monitored over 3 campaigns in 2010 at the PNS site.

\section{Clustering by shape (similarity)}

Four clusters of days were identified (Fig. S3). Table 1 shows the frequency of each day of the 


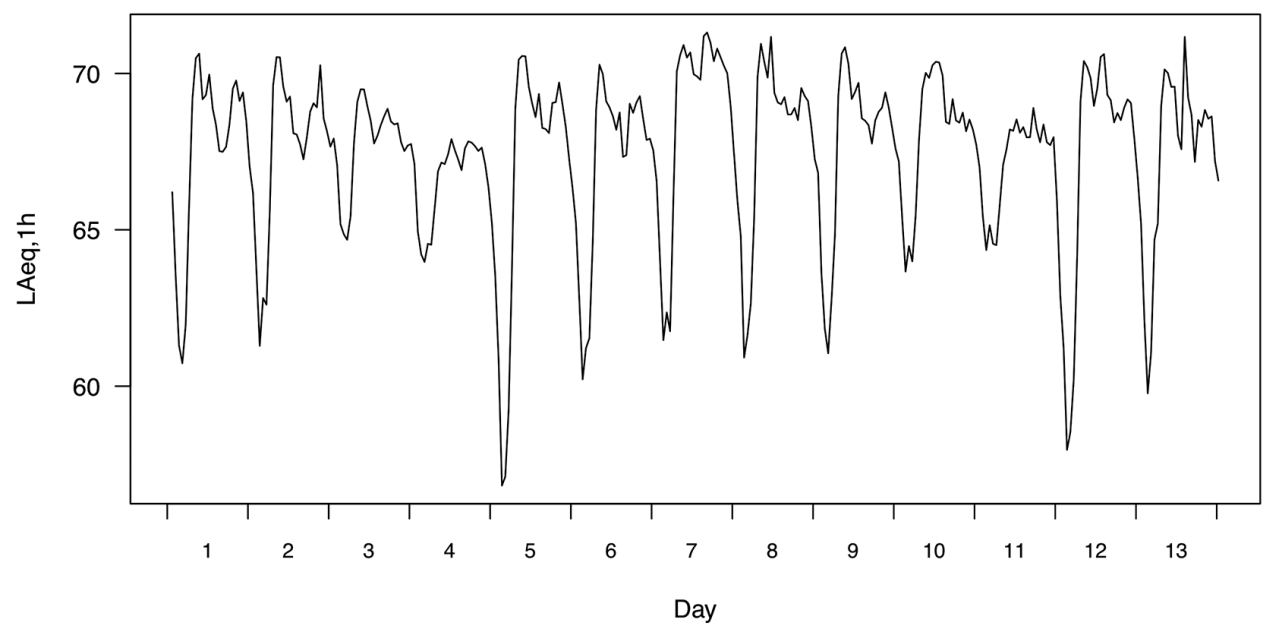

Figure 1. Continuous recording of $\mathrm{L}_{\text {Aeq, } 1 \mathrm{~h}}$ at Independencia Avenue site (Thursday, May 29, 2008 through Tuesday, June 10, 2008).
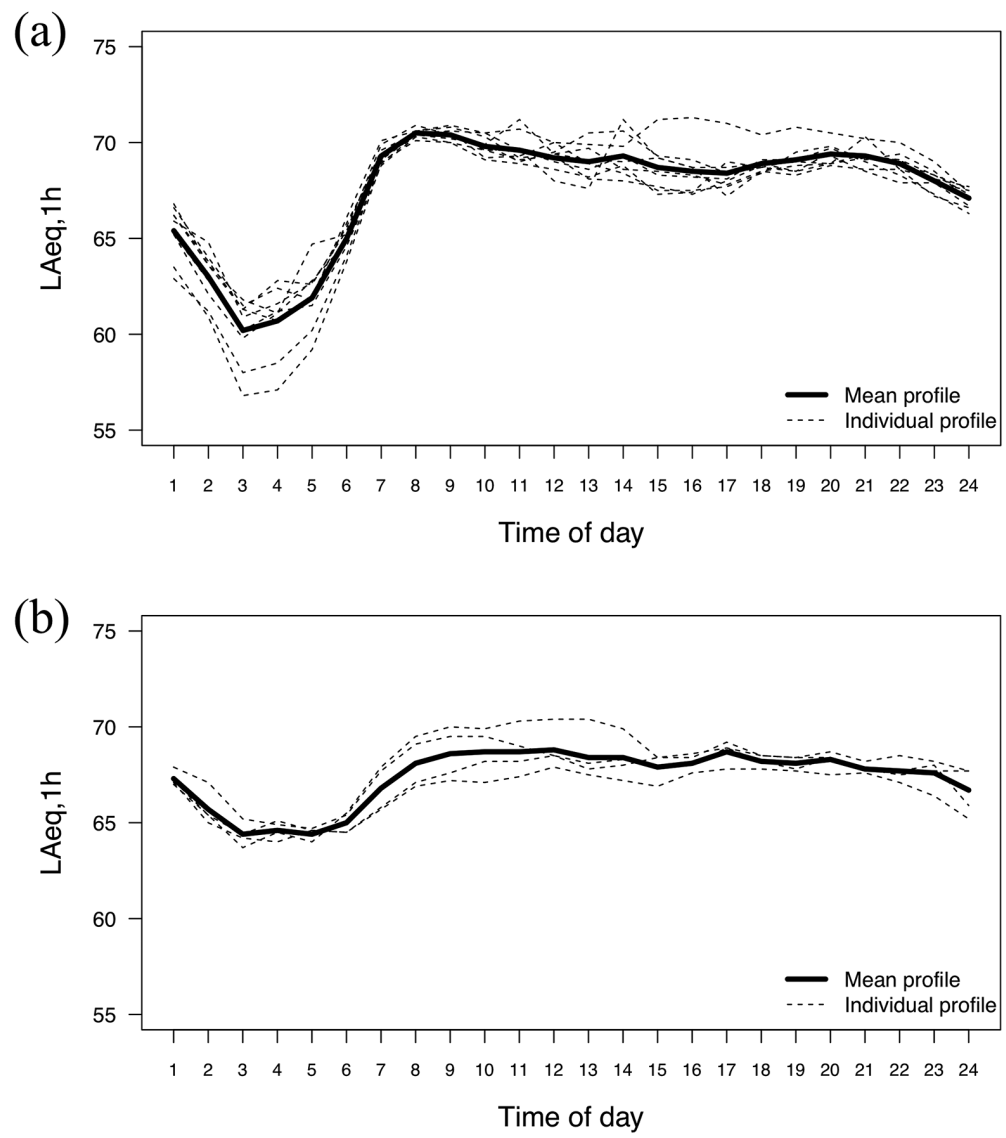

Figure 2. Mean daily noise profiles for Independencia Avenue site. Dashed lines are the individual profiles of the days that form each cluster. Top: a) Weekday; bottom: b) Weekend. 

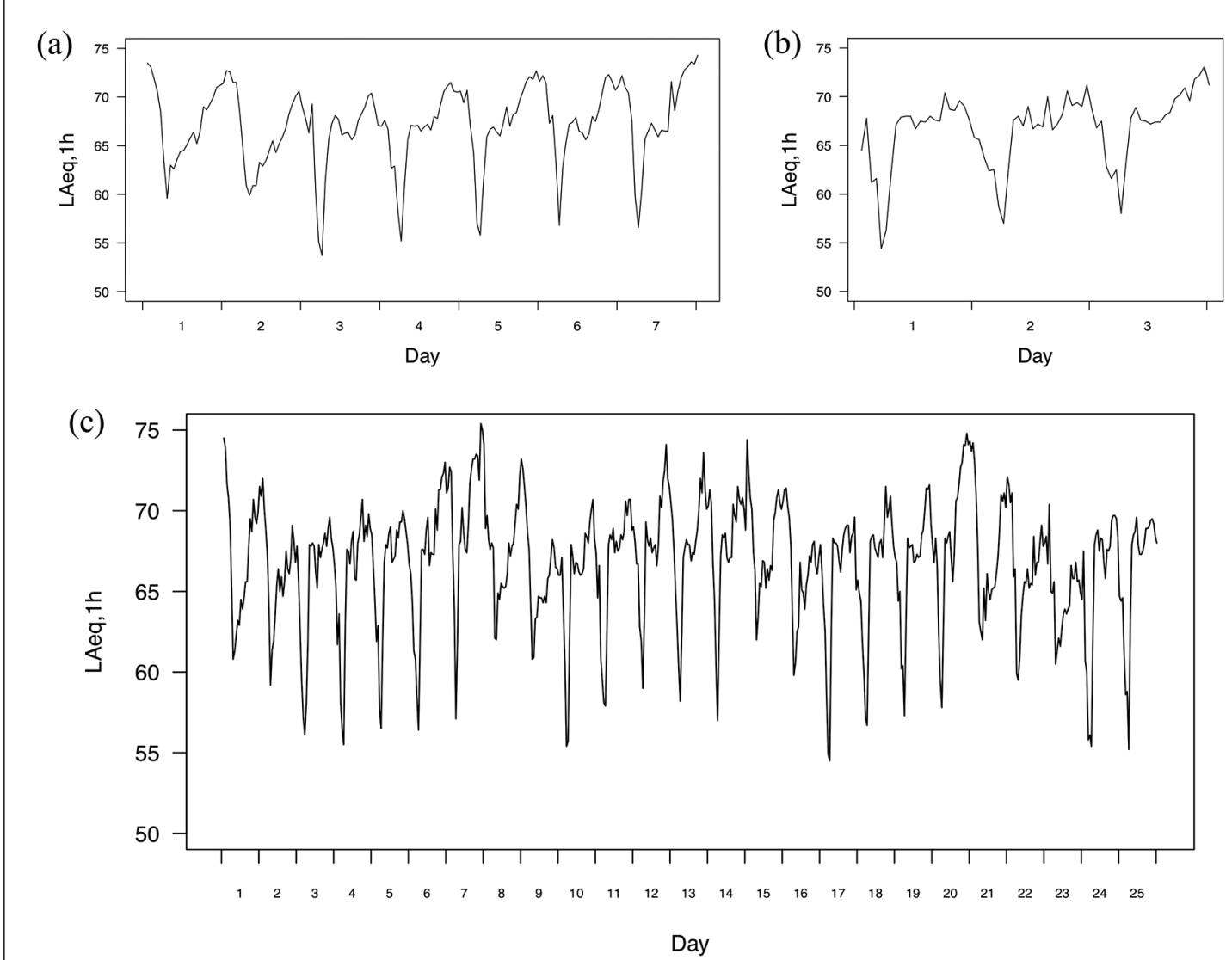

Figure 3. Continuous recording of $\mathrm{L}_{\mathrm{Aeq}, \mathrm{h}}$ at Pío Nono Street site (2010). Top left: a) Saturday, February 20 through Friday, February 26; top right: b) Tuesday, April 20 through Thursday, April 22; bottom: c) Saturday, May 1 through Tuesday, May 25.

Table 1. Distribution of days of the week in profiles clustered by shape for Pío Nono Street site

\begin{tabular}{|lcccc|}
\hline Day of the & $\begin{array}{c}\text { Cluster } \\
\text { week }\end{array}$ & $\begin{array}{c}\text { Cluster } \\
\mathbf{2}\end{array}$ & $\begin{array}{c}\text { Cluster } \\
\mathbf{3}\end{array}$ & $\begin{array}{c}\text { Cluster } \\
\mathbf{4}\end{array}$ \\
\hline Monday & 5 & 0 & 0 & 0 \\
Tuesday & 6 & 0 & 0 & 0 \\
Wednesday & 4 & 0 & 1 & 0 \\
Thursday & 4 & 0 & 1 & 0 \\
Friday & 0 & 1 & 3 & 0 \\
Saturday & 0 & 4 & 0 & 1 \\
Sunday & 0 & 5 & 0 & 0 \\
\hline Total & 19 & 10 & 5 & 1 \\
\hline
\end{tabular}

week in each cluster (clusters are numbered according to size). The following clusters were found: a) Cluster 1 (second cluster from the left in the dendrogram) contains the Mondays-Thursdays from April and May (autumn) and Monday and Tuesday from February (summer). This result indicates that the daily patterns for the first four days of week have similar shapes, but in summer, only Monday and Tuesday would follow this pattern. b) Cluster 2 (far right cluster in the dendrogram) contains Saturdays and Sundays, and Friday, May 21, being the latter a holiday. Thus, the results for Cluster 2 indicate that weekend days, in addition to holidays that fall on the day before a weekend, have similar pattern shapes. c) Cluster 3 (first cluster on the left in the dendrogram) contains 
three Fridays plus Wednesday and Thursday from February (summer). Therefore, this result indicates that the daily patterns for Fridays, as well as summer Wednesdays and Thursdays, have a distinctive shape that differs from other weekdays. d) Cluster 4 contains only Saturday, May 8. This finding is thought as a singularity and was excluded from further analyses.

\section{Clustering by noise level (distance)}

A separate analysis was performed within each cluster obtained in the previous phase:

i) Fig. S4a shows the dendrogram obtained for Cluster 1, where two groups were identified. The first group consists of five Mondays (May $3,10,17$, and 24 and February 22), five Tuesdays (May 4, 11, 18, and 25 and April 20), and two Wednesdays (April 21 and May 5). This analysis, therefore, identified a profile for Mondays, Tuesdays, and Wednesdays, represented by the mean profile shown in Fig. 4 a.

The second group contained one Tuesday (February 23), two Wednesdays (May 12 and 19), and three Thursdays (May 6 and 13 and April 22). As Wednesday, May 19 preceded Thursday, May 20 and then the holiday Friday, May 21, its noise levels could be expected to be similar to those of a typical Thursday. Therefore, the mean profile of this group represents the daily pattern of a typical Thursday, as shown in Fig. $4 \mathrm{~b}$.

ii) Fig. S4b shows the dendrogram computed for Cluster 2, where two groups were identified. One of the groups contains three Saturdays (May 1 and 15 and February 20) and one Friday (May 21). As seen before, Friday, May 21 is similar to a typical Saturday. Therefore, the mean profile of this group represents the daily pattern of a typical Saturday, as shown in Fig. $4 \mathrm{~d}$.

The other group contains four Sundays (May 2, 9, and 16 and February 21) and one Saturday (May 22). As May 22 was immediately preceded by the holiday Friday, May 21, it could be expected to be similar to a typical Sunday. Sunday, May 23 did not subcluster with this group, possibly due to being preceded by Friday, May 21 and Saturday, May 22. Therefore, the mean profile of this group represents the daily pattern of a typical Sunday, as shown in Fig. 4e. iii) Fig. S4c shows the dendrogram obtained for Cluster 3. Friday, May 7 did not meet the criterion value for inclusion in this cluster and was thought as a singularity. Therefore, the mean profile of this group represents the daily pattern of a typical Friday, as shown in Fig. 4c.

\subsection{Assessment of acoustic indicators and comparison between the sites}

With obtained daily noise patterns, acoustic descriptors for each site were computed ${ }^{4}$. These are shown in Table 2. At IA both weekdays and weekend show the greatest sound levels for daytime (defined for $\mathrm{L}_{\text {day }}$ from 7 am to $7 \mathrm{pm}$ ) and the lowest for nighttime ( $\mathrm{L}_{\text {night }}$, from $11 \mathrm{pm}$ to $7 \mathrm{am}$ ). The silentest hour is between 2 and 3 am for both daily patterns, also between 4 and 5 am for weekend. The noisiest hour is between 7 and 8 am in weekdays and between $11 \mathrm{am}$ and $12 \mathrm{pm}$ in weekend. In constrast, in a mainly night leisure zone as Bellavista neighborhood, where PNS is the busiest street, there are noticeable differences depending on the day of the week. Thereby, in a weekday the noisiest period is the evening $\left(\mathrm{L}_{\text {evening, }}\right.$, from $7 \mathrm{pm}$ to $11 \mathrm{pm}$ ), and sound level is higher at daytime than at nighttime. The minimum and maximum hourly sound levels are produced between 5 and 6 am and between 8 and $9 \mathrm{pm}$, respectively. On the other hand, on weekend the nighttime is the noisiest period, followed by the evening. The silentest hour is between 6 and $7 \mathrm{am}$, and the noisiest one is between 0 and $1 \mathrm{am}$, which is according to the characteristics of the neighborhood.

\section{Discussion}

Different daily noise patterns were identified for two urban sites from Santiago based on continuous measurements of sound pressure level. Noise patterns of PNS are notoriously different from those of IA, as is expected for sites where the main sound source is not vehicular traffic $c^{45,47,48}$. Also, results indicate that there are seasonal differences, as have been observed in other researches ${ }^{45,46}$.

The results are consistent with the expected acoustic behavior of the selected sites. IA is a major thoroughfare with considerable commercial activity as well as bus and car traffic. This type of street might be expected to show typical urban acoustic patterns that do not vary significantly by 

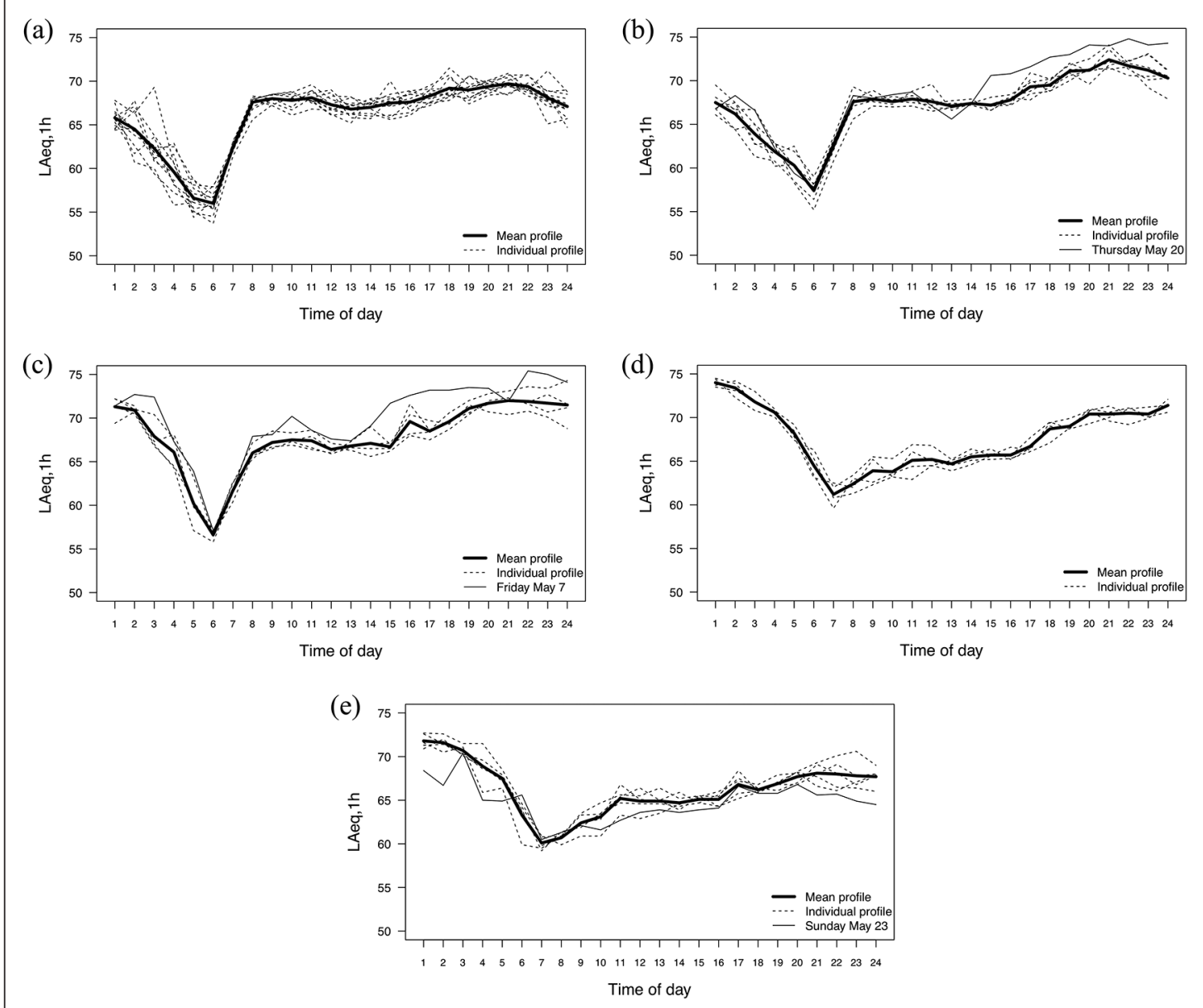

Figure 4. Mean daily noise profiles for Pío Nono Street site. Dashed lines are the individual profiles of the days that form each cluster. Top left: a) Mondays through Wednesdays; top right: b) Thursdays (May 20 excluded from calculation of the mean); middle left: c) Fridays (May 7 excluded from calculation of the mean); middle right: d) Saturdays; bottom: e) Sundays (May 23 excluded from calculation of the mean).

Table 2. Acoustic descriptors for different daily patterns in the two studied sites

\begin{tabular}{|c|c|c|c|c|c|c|c|}
\hline \multirow[t]{2}{*}{ Descriptor } & \multicolumn{2}{|c|}{$\begin{array}{l}\text { Main street with heavy } \\
\text { vehicular traffic } \\
\text { (Independencia Avenue) }\end{array}$} & \multicolumn{5}{|c|}{$\begin{array}{l}\text { Street with pedestrian traffic and leisure activity } \\
\text { (Pío Nono Street) }\end{array}$} \\
\hline & Weekday & Weekend & $\begin{array}{l}\text { Monday- } \\
\text { Wednesday }\end{array}$ & Thursday & Friday & Saturday & Sunday \\
\hline$L_{\text {day }}$ & 69.3 & 68.4 & 67.9 & 68.3 & 68.1 & 65.9 & 65.0 \\
\hline Levening & 68.9 & 67.9 & 69.2 & 71.6 & 71.8 & 70.4 & 67.9 \\
\hline$L_{\text {night }}$ & 65.1 & 65.7 & 63.3 & 65.4 & 68.2 & 70.9 & 69.0 \\
\hline$L_{\text {den }}$ & 72.9 & 72.8 & 71.6 & 73.6 & 75.2 & 76.9 & 75.0 \\
\hline Leq, $h$ min & $\begin{array}{c}60.2 \\
(2-3 \mathrm{am})\end{array}$ & $\begin{array}{c}64.4 \\
(2-3 \& 4-5 \mathrm{am})\end{array}$ & $\begin{array}{c}56.0 \\
(5-6 \mathrm{am})\end{array}$ & $\begin{array}{c}57.4 \\
(5-6 \mathrm{am})\end{array}$ & $\begin{array}{c}56.6 \\
(5-6 \mathrm{am})\end{array}$ & $\begin{array}{c}61.2 \\
(6-7 \mathrm{am})\end{array}$ & $\begin{array}{c}60.1 \\
(6-7 \mathrm{am})\end{array}$ \\
\hline Leq, $h$ max & $\begin{array}{c}70.5 \\
(7-8 \mathrm{am})\end{array}$ & $\begin{array}{c}68.8 \\
(11-12 \mathrm{am})\end{array}$ & $\begin{array}{c}69.7 \\
(8-9 \mathrm{pm})\end{array}$ & $\begin{array}{c}72.4 \\
(8-9 \mathrm{pm})\end{array}$ & $\begin{array}{c}72.0 \\
(8-9 \mathrm{pm})\end{array}$ & $\begin{array}{c}74.0 \\
(0-1 \mathrm{am})\end{array}$ & $\begin{array}{c}71.8 \\
(0-1 \mathrm{am})\end{array}$ \\
\hline
\end{tabular}


day of the week. Indeed, the results indicate that weekdays and weekend days vary in terms of sound level but not in terms of pattern shape.

PNS, in contrast, is characterized by intense recreational activity, especially at night, and noise patterns differ from those of IA. The street has numerous bars and clubs with heavy pedestrian and vehicular traffic. Noise levels substantially increase on Thursday, Friday, and Saturday nights. Early Saturday and Sunday mornings (which are effectively continuations of Friday and Saturday nights, respectively) also have noise levels about 5 dBA higher than weekday mornings. Additionally, results suggest different daily and weekly noise patterns in summer, related to a greater and more frequent attendance at leisure places.

For both sites sound pressure levels exceed 55 $\mathrm{dBA}$ in $\mathrm{L}_{\text {night, }}$, that is the recommended limit value for avoiding several adverse health effects, being the most relevant sleep disturbance and high annoyance, and also risk increase of cardiovascular disease ${ }^{1,7}$. People living in those zones may be also at high risk of suffer interference with daily activities, feelings, sleep, or rest, and anger, displeasure, exhaustion, and other stress-related symptoms ${ }^{49}$. Particularly, environmental noise levels observed at IA also are of concern because this neighbouhood is an hospitalary area and may increase the natural high level of intrahospitalary noise.
The small to moderate sample sizes limit this to be just an exploratory study. Future studies with longer-term measurements may produce clearer and more generalizable patterns. Defining such patterns would allow researchers to select representative periods during representative days to perform discrete measurements, obtain the $\mathrm{L}_{\text {Aeq, } 1 \mathrm{~h}}$, and then compute descriptors such as $\mathrm{L}_{\text {day }}$, $\mathrm{L}_{\text {evening, }}$ $\mathrm{L}_{\text {night }}$ or $\mathrm{L}_{\mathrm{den}}$, which is a common interest in noise monitoring and mapping.

Another limitation of this study is that the noise measurements were made in 2008 and 2010, and urban environment is likely to have suffered changes in time. Nevertheless, based in our knowledge and what we have observed in situ through these years, these sites do not show noticeable changes that could imply important differences in their general patterns of noise. However, many paving works on IA have increased the noise level in this area. Consequently, noise levels at both sites, for different reasons, are above the accepted standard levels for adequate well-being and good health of people living in these neighborhoods.

Acknowledgements: The authors are grateful to the Ministerial Secretary of Health of the Metropolitan Region of Chile, especially the Environmental Acoustics Unit, for providing the noise level data analyzed in this research.

\section{Suplementary material}

The average correlation coefficient for two clusters, A and B, is defined as:

$$
r_{\mathrm{AB}}=\frac{1}{n_{\mathrm{A}} n_{\mathrm{B}}} \sum_{i=1}^{n_{\mathrm{A}}} \sum_{i^{\prime}=1}^{n_{\mathrm{B}}} r_{\mathrm{AB} i i^{\prime}}
$$

where $n_{\mathrm{A}}$ and $n_{\mathrm{B}}$ are the number of observations (days) in clusters $\mathrm{A}$ and $\mathrm{B}$, respectively, and $r_{\mathrm{ABii}}$ is the correlation coefficient for day $i$ of cluster $A$ and day $i^{\prime}$ of cluster $B$.

The absolute or Minkowski distance between days $j$ and $j^{\prime}$, with $r=1$, is

$$
d_{j j^{\prime}}=\sum_{k=1}^{24}\left|x_{j(k)}-x_{j^{\prime}(k)}\right|
$$


Figure S1. Two (hypothetical) daily noise profiles with similar shape, where absolute distance between sound levels for $k$-th hour is shown.

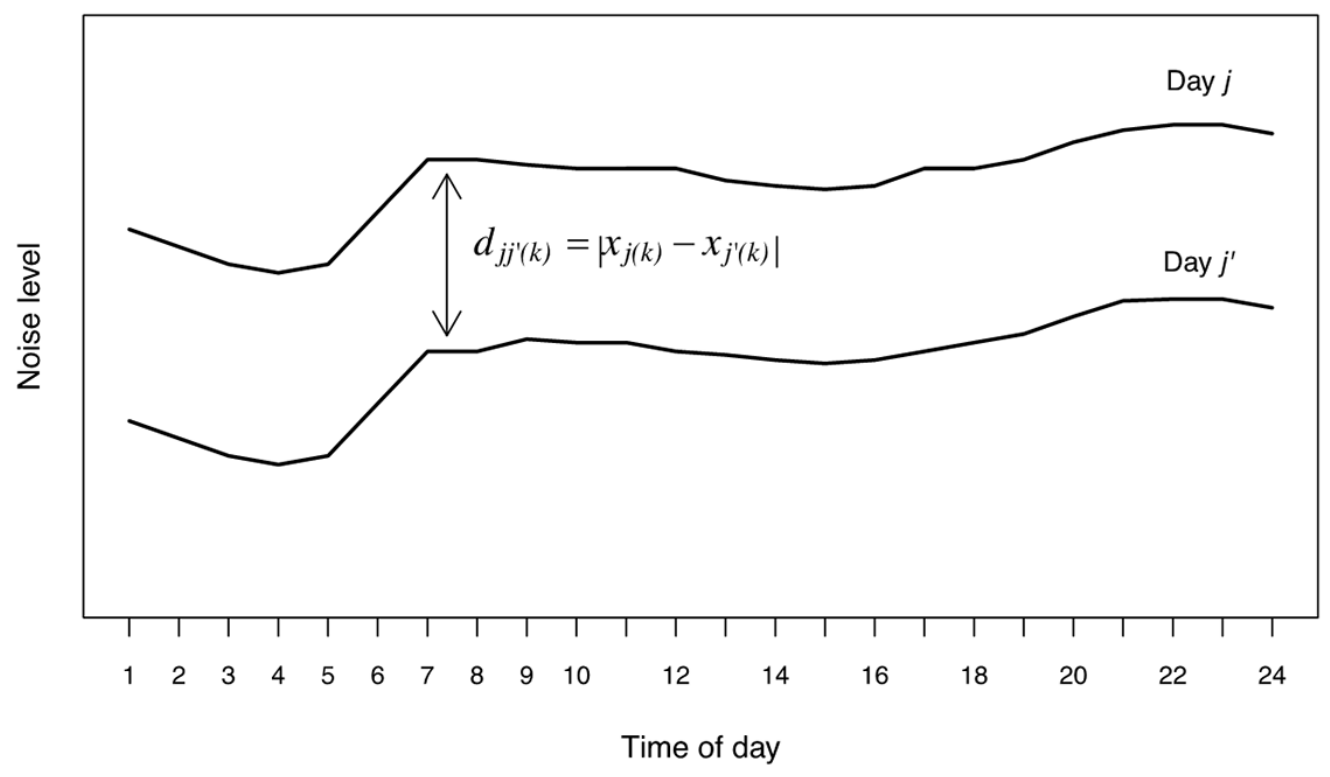

Figure S2. Dendograms of noise profiles for Independencia Avenue site. Left: a) Clustering by shape; right: b) Subclustering by noise level.

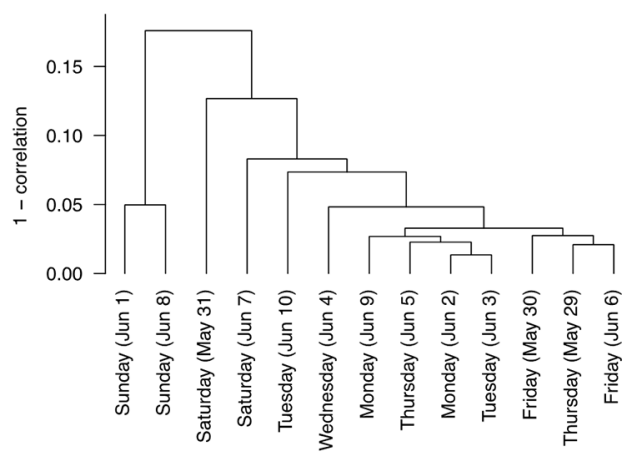

(a)

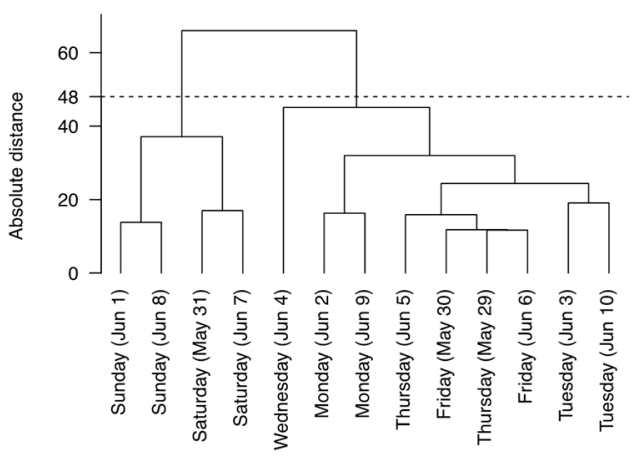

(b) 
Figure S3. Dendrogram of noise profiles clustered by shape for Pío Nono Street site.

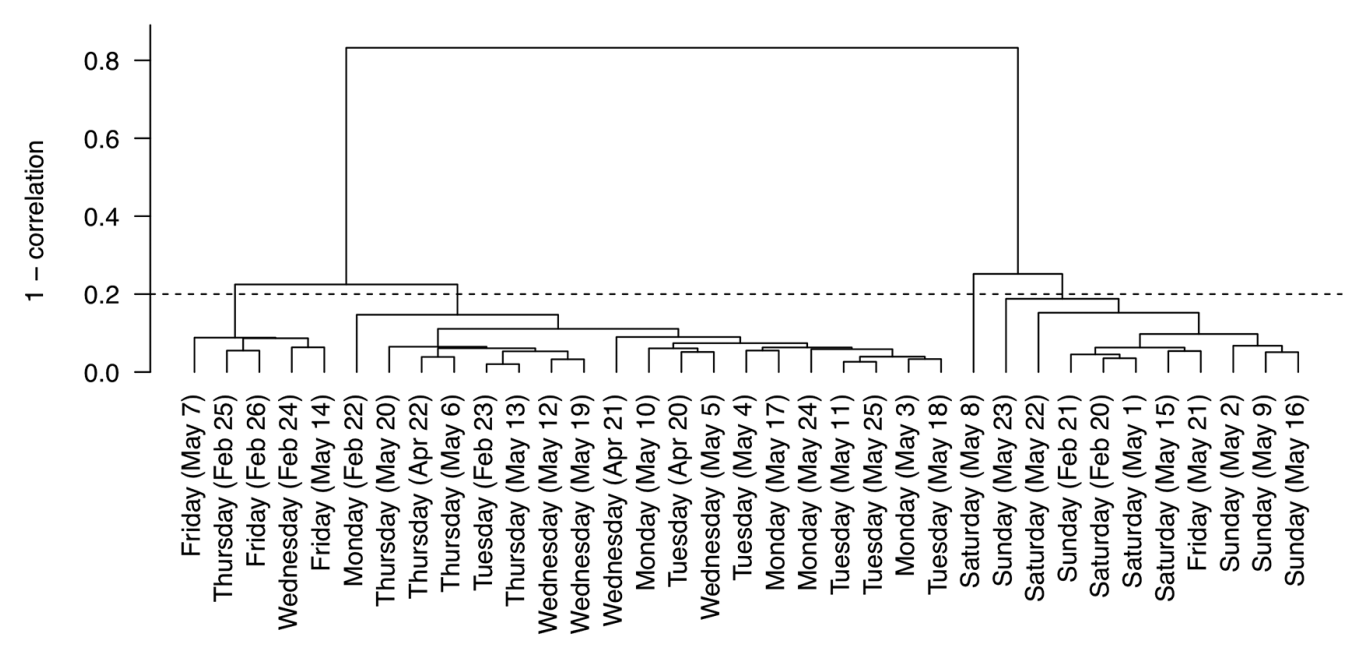

Figure S4. Dendograms of noise profiles subclustered for noise level for Pío Nono Street site. Top: a) Cluster 1 from Phase 1; bottom left: b) Cluster 2 from Phase 1; bottom right: c) Cluster 3 from Phase 1.
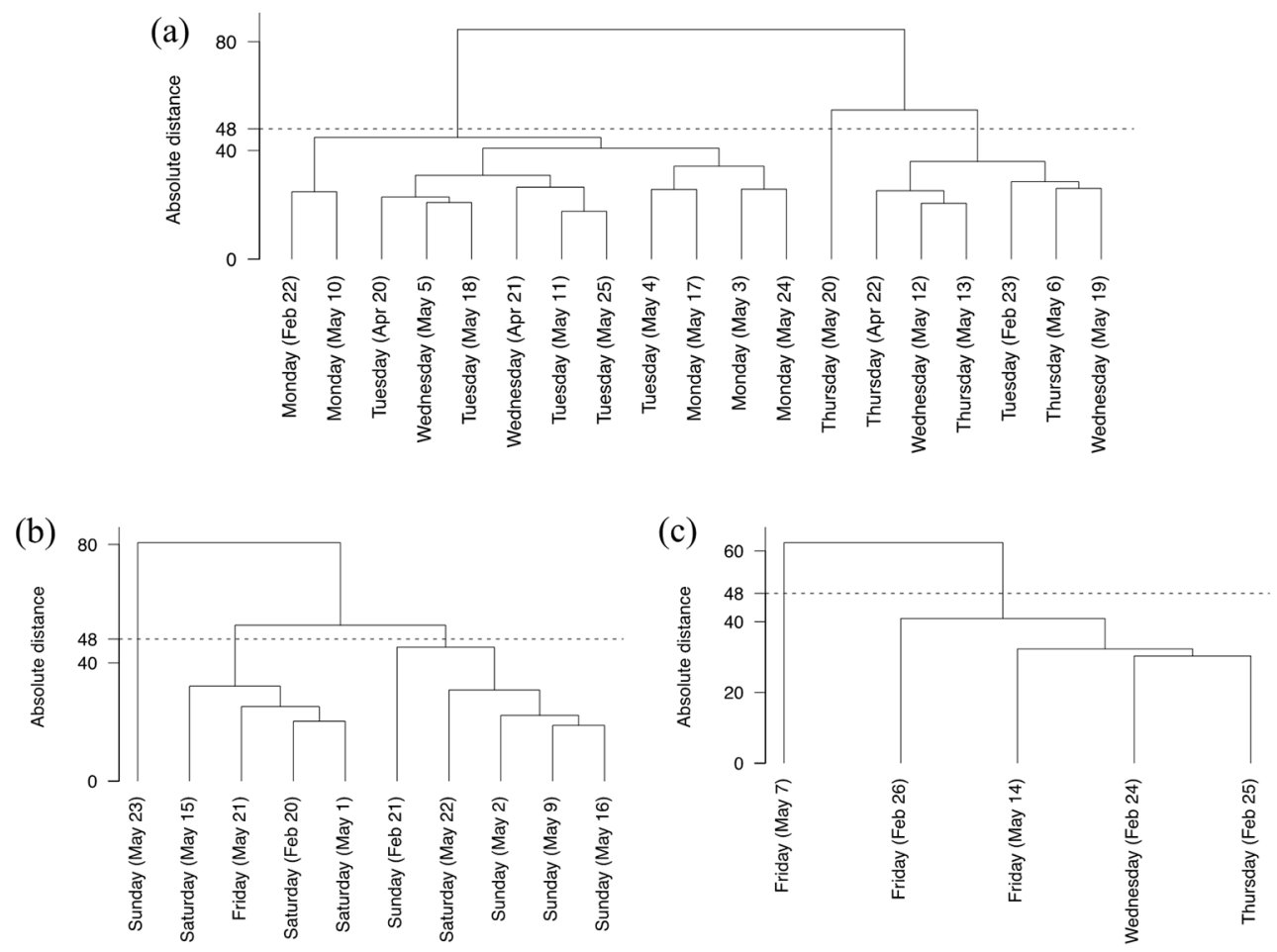


\section{References}

1. Basner M, Babisch W, Davis A, et al. Auditory and non-auditory effects of noise on health. Lancet 2014; 383 (9925): 1325-32. doi: 10.1016/S0140-6736(13)61613-X

2. enHealth Council. The Health Effects of Environmental Noise - Other than Hearing Loss. Canberra: Department of Health and Ageing, Population Health Division; 2004. http://www.aph.gov.au/DocumentStore. ashx?id=501b0871-8dbe-4254-9158-8f08f39c5a9c.

3. European Commission (EC). THEMATIC ISSUE: Noise Impacts on Health. Bristol; 2015. doi: 10.2779/53698

4. European Commission (EC). Directive 2002/49/EC of the European Parliament and of the Council of 25 June 2002 relating to the assessment and management of environmental noise. 2002. http://eur-lex.europa.eu/ legal-content/EN/TXT/?uri=CELEX:32002L0049.

5. U.S. Federal Aviation Administration (FAA). FAR Part 150 - Airport Noise Compatibility Planning. 1981. http://www.ecfr.gov/cgi-bin/text-idx?SID=6084018be$2 \mathrm{db} 3 \mathrm{f} 600273 \mathrm{fa} 48603800 \mathrm{~b} 2 \& \mathrm{tpl}=/$ ecfrbrowse/Tit le14/14cfr150_main_02.tpl.

6. World Health Organization (WHO). Guidelines for Community Noise. (Berglund B, Lindvall T, Schwela DH, eds.). Geneva: WHO; 1999.

7. World Health Organization (WHO). Night Noise Guidelines for Europe. (Hurtley C, ed.). Copenhagen: WHO Regional Office for Europe; 2009. http://www.euro.who. int/_data/assets/pdf_file/0017/43316/E92845.pdf.

8. U.S. Environmental Protection Agency (EPA). The Urban Noise Survey. Washington D.C.: EPA, Office of Noise Abatement and Control; 1977.

9. Fiedler PEK, Zannin PHT. Evaluation of noise pollution in urban traffic hubs-Noise maps and measurements. Environ Impact Assess Rev 2015; 51: 1-9. doi: 10.1016/j. eiar.2014.09.014

10. Intendencia Regional de la Región Metropolitana. Estudio base de generación de niveles de ruido en el Gran Santiago [Base study of generation of noise levels in Gran Santiago]. 1989. http://www.socha.cl/wp-content/ uploads/2013/06/02_AMarzzano_2006a.pdf.

11. Ko JH, Chang S Il, Lee BC. Noise impact assessment by utilizing noise map and GIS: A case study in the city of Chungju, Republic of Korea. Appl Acoust.2011; 72 (8): 544-50. doi: 10.1016/j.apacoust.2010.09.002

12. Martín MÁ, Tarrero AI, Machimbarrena M, González J, González de Garibay V. A methodology to study noise annoyance and to perform Action Plans follow up using as input an existing survey and noise map: Application to the city of Málaga (Spain). Appl Acoust 2011; 72 (8): 495-504. doi: 10.1016/j.apacoust.2011.02.005
13. Ministerio del Medio Ambiente (MMA). Elaboración de mapa de ruido del Gran Santiago mediante software de modelación [Elaboration of noise map of Great Santiago using modelling software]. 2011.

14. Phan HYT, Yano T, Phan HAT, Nishimura T, Sato T, Hashimoto Y. Community responses to road traffic noise in Hanoi and Ho Chi Minh City. Appl Acoust 2010; 71 (2): 107-14. doi: 10.1016/j.apacoust.2009.08.004

15. Servicio de Salud Metropolitano del Ambiente (SESMA). Actualización de niveles de ruido del Gran Santiago 1989-2001 [Update of noise levels in Gran Santiago 1989-2001]. 2001.

16. Sommerhoff J, Recuero M, Suárez E. Community noise survey of the city of Valdivia, Chile. Appl Acoust 2004; 65: 643-56. doi: 10.1016/j.apacoust.2004.01.003

17. Xie H, Kang J, Tompsett R. The impacts of environmental noise on the academic achievements of secondary school students in Greater London. Appl Acoust 2011; 72 (8): 551-5. doi: 10.1016/j.apacoust.2010.10.013

18. U.S. Federal Transit Administration (FTA). Transit Noise and Vibration Impact Assessment. (Hanson CE, Towers DA, Meister LD, eds.). Washington D.C.: FTA, Office of Planning and Environment; 2006.

19. DeVor RE, Schomer PD, Kline WA, Neathamer RD. Development of temporal sampling strategies for monitoring noise. J Acoust Soc Am 1979; 66 (3): 763-71. doi: 10.1121/1.383678.

20. Doygun H, Kuşat Gurun D. Analysing and mapping spatial and temporal dynamics of urban traffic noise pollution: A case study in Kahramanmaraş, Turkey. Environ Monit Assess 2008; 142 (1-3): 65-72. doi: 10.1007/ s10661-007-9908-7.

21. Gómez Escobar V, Barrigón Morillas JM, Rey Gozalo G, et al. Acoustical environment of the medieval centre of Cáceres (Spain). Appl Acoust 2012; 73 (6-7): 673-685. doi: 10.1016/j.apacoust.2012.01.006.

22. Mateus M, Dias Carrilho JA, Gameiro da Silva MC. Assessing the influence of the sampling strategy on the uncertainty of environmental noise measurements through the bootstrap method. Appl Acoust 2015; 89: 159-65. doi: 10.1016/j.apacoust.2014.09.021.

23. Mehdi MR, Kim M, Seong JC, Arsalan MH. Spatio-temporal patterns of road traffic noise pollution in Karachi, Pakistan. Environ Int 2011; 37 (1): 97-104. doi: 10.1016/j.envint.2010.08.003.

24. Piccolo A, Plutino D, Cannistraro G. Evaluation and analysis of the environmental noise of Messina, Italy. Appl Acoust 2005; 66 (4): 447-465. doi: 10.1016/j.apacoust.2004.07.005.

25. Brocolini L, Lavandier C, Quoy M, Ribeiro C. Measurements of acoustic environments for urban soundscapes: 
Choice of homogeneous periods, optimization of durations, and selection of indicators. J Acoust Soc Am 2013; 134 (1): 813-21. doi: 10.1121/1.4807809.

26. Chung E, Rosalion N. Short Term Traffic Flow Prediction. In: Proceedings of the 24th Australasian Transport Research Forum. Hobart, Tasmania; 2001. http://www. atrf.info/papers/2001/2001_Chung_Rosalion.pdf.

27. Guardiola IG, Leon T, Mallor F. A functional approach to monitor and recognize patterns of daily traffic profiles. Transp Res Part B 2014; 65: 119-36. doi: 10.1016/j. trb.2014.04.006.

28. Jiang S, Ferreira J, González MC. Clustering daily patterns of human activities in the city. Data Min Knowl Discov 2012; 25 (3): 478-510. doi: 10.1007/s10618-0120264-z.

29. Kim C-H, Koo B-G, Park JH. Short-term Electric Load Forecasting Using Data Mining Technique. J Electr Eng Technol 2012; 7 (6): 807-13. doi: 10.5370/ JEET.2012.7.6.807.

30. Martinez-Álvarez F, Troncoso A, Riquelme JC, Aguilar-Ruiz JS. Energy Time Series Forecasting Based on Pattern Sequence Similarity. IEEE Trans Knowl Data Eng 2011; 23 (8): 1230-43. doi: 10.1109/TKDE.2010.227.

31. Panapakidis IP. Clustering based day-ahead and hourahead bus load forecasting models. Electr Power Energy Syst 2016; 80: 171-8. doi: 10.1016/j.ijepes.2016.01.035.

32. Rodrigues F, Cardeira C, Calado JMF. The daily and hourly energy consumption and load forecasting using artificial neural network method: a case study using a set of 93 households in Portugal. Energy Procedia 2014; 62: 220-9. doi: 10.1016/j.egypro.2014.12.383.

33. Weijermars W, van Berkum E. Analyzing highway flow patterns using cluster analysis. In: Proceedings of the 8th International IEEE Conference on Intelligent Transportation Systems. Vienna; 2005:831-836. http:// doc.utwente.nl/54970/.

34. Municipalidad de Independencia. Ordenanza local del Plan Regulador Comunal de Independencia. 2014. https://www.independencia.cl/plan-regulador/.

35. Gobierno Regional de la Región Metropolitana (GORE). Plan Regulador Metropolitano de Santiago (Resolución No. 20/1994). 1994. https://metropolitana.minvu.cl/ wp-content/files_mf/1549050083OrdenanzaPRMSENERO2019.pdf.
36. Municipalidad de Providencia. Ordenanza local del Plan Regulador Comunal de Providencia. 2008. https://transparencia.providencia.cl/tact/Carpeta/Listado/23323.

37. Municipalidad de Recoleta. Ordenanza local del Plan Regulador Comunal de Recoleta. 2005. http://www. recoletatransparente.cl/web/plan_regulador.html.

38. Guisande González C, Vaamonde Liste A. Gráficos Estadísticos y Mapas Con R. Madrid: Díaz de Santos; 2012.

39. Logan M. Biostatistical Design and Analysis Using R. Oxford: Wiley-Blackwell; 2010. doi: 10.1002/9781444319620.

40. Lucas A. amap: Another Multidimensional Analysis Package. 2014. http://cran.r-project.org/package=amap.

41. R Core Team. R: A language and environment for statistical computing. 2018. http://r-project.org/.

42. Rencher AC. Methods of Multivariate Analysis. 2nd ed. New York: John Wiley \& Sons, Inc.; 2002.

43. Johnson RA, Wichern DW. Applied Multivariate Statistical Analysis. 6th ed. New Jersey: Pearson Prentice Hall; 2007.

44. Murtagh F, Contreras P. Algorithms for hierarchical clustering: an overview. WIREs Data Min Knowl Discov. 2012;2(February):86-97. doi: 10.1002/widm.53.

45. Geraghty D, O'Mahony M. Investigating the temporal variability of noise in an urban environment. Int J Sustain Built Environ 2016; 5 (1): 34-45. doi: 10.1016/j. ijsbe.2016.01.002.

46. Mioduszewski P, Ejsmont JA, Grabowski J, Karpinski D. Noise map validation by continuous noise monitoring. Appl Acoust 2011; 72: 582-9. doi: 10.1016/j. apacoust.2011.01.012.

47. Hueso MC, Giménez A, Sancho S, Gaja E. Measurement techniques of noise level in various urban scenarios. Day selection and representative period. Appl Acoust. 2017; 116: 216-28. doi: 10.1016/j.apacoust.2016.09.033.

48. Khaiwal R, Singh T, Tripathy JP, et al. Assessment of noise pollution in and around a sensitive zone in North India and its non-auditory impacts. Sci Total Environ 2016; 566-67: 981-7. doi: 10.1016/j.scitotenv.2016.05.070.

49. Öhrström E, Skånberg A, Svensson H, Gidlöf-Gunnarsson A. Effects of road traffic noise and the benefit of access to quietness. J Sound Vib 2006; 295: 40-59. doi: 10.1016/j.jsv.2005.11.034. 